\title{
Evaluering og studieordninger
}

\author{
Mads Hermansen, professor i paedagogik og studieleder ved HA-psyk studienavn, Copenhagen \\ Business School, Kobenhavn. Mads Hermansen arbejder bl.a med curriculum \\ og studieprogression.
}

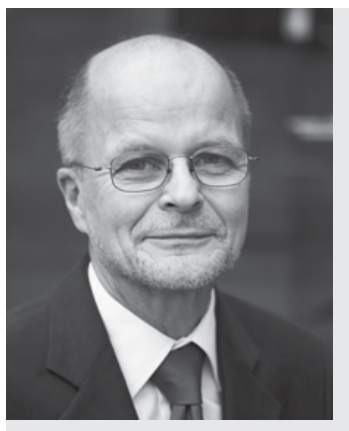

Mads Hermansen, professor, dr pæd. Studieleder på HA(psyk) på Handelshøjskolen i København (CBS) og tilknyttet CBS Learning Lab. Forskningsleder af det Rockwool Fond finansierede projekt Dansk Skolekultur om vaner og disciplin i folkeskolen. Har skrevet en lang række bøger om læring, senest Relearning (2005).

At skrive evalueringsformer ind $i$ studieordningerne, der afspejler generalist-kompetencemål som f.eks. proceskompetence og selvrefleksion er (også) arbejdsområde for studiencevnene. Artiklen giver et eksempel på, hvordan eksamener, der evaluerer sådanne kompetencer, kan udformes.

Studieordningerne er de studerendes retsgrundlag, samtidig er det studienævnenes mulighed for i dialog med underviseren at udforme det grundlag, som både kan være inspirerende og foreskrivende. Det følgende er et eksempel på dette arbejde.

Læg især mærke til at eksamensformen aktivt søger at afspejle undervisningsform og de temaer og kompetencer, de studerende har skullet erhverve i første semester.

Studienævnene har reelt rollen som dem, der laver udkast til studieordningen på det enkelte studium. Formelt set er det dekan eller rektor, som godkender efter en juridisk gennemgang, der tilser, at alt er i overensstemmelse med love og bekendtgørelser.

Det er altså en ikke ringe indflydelse, studienævnet har på evalueringens form og indhold og eksamensordning. Mange steder er disse forhold imidlertid ikke særligt aktivt inde i studienævnenes arbejde.

Det følgende er eksempel på, hvordan vi i det lille studienævn, jeg er studieleder for, har grebet sammenhængen an. Det vil jeg i kort form vise i det følgende, hvor undervisningens indhold og form på første seme- ster af kombinationsuddannelsen af erhvervsøkonomi og psykologi lægger beskrivelse til.

I studieordningens $\mathbb{} 6$ står der om indholdet på første semester »Stk. 2. Tre temablokke på første semester med fokus på fortællinger i organisationer, læringsprocesser samt identitetsdannelse:

Fortællinger i organisationer, der inddrager:

- Den personligt socialkonstruerede biografi/narrativ om 'selv' og organisation

- Læringsprocesser

- Den individuelle læringsproces og virksomhedens læringsproces

- Identitetsdannelse

- Den personlige identitetsdannelse, samt virksomhedens identitetsdannelse og strategi«

Der arbejdes med stoffet på et overvejende induktivt grundlag, hvor øvelser, rollespil, casearbejde, træningsgrupper (fx forrummetode og reflekterende team) ${ }^{1}$ og fremstilling af analyser lavet i studiegrupper er eksempler på arbejdsmetoder. De studerende er i hele semestret organiseret i grupper på 5, som er sammensat efter at repræsentere kompletterende stile i en tænkestilstestning (R. Sternberg 2003) ${ }^{2}$.

Selve eksamenssituationen ved afslutning af semester varer $i$ alt tre timer, og to grupper er sammen. Der skal i evalueringen lægges vægt på følgende: Igen citeres der fra studieordningen, nu $\ 14$ ):

"Følgende parametre skal inddrages $\mathrm{i}$ begrundelsen:

- Faglig såvel som tværfaglig eksponering af relevant erhvervsøkonomisk og psykologisk teori herunder blandt andet personlighedspsykologi, læreprocesteori, systemisk kommunikationsteori, videnskabsteori samt teori om virksomhedens opstart, dynamik og strukturelle udvikling, organisatoriske læreprocesser og kompetenceudvikling samt organisationers strategi og identitet.

- Endvidere indgår det i bedømmelsen på hvilken måde de studerende har været procesmæssigt kom- 
petente i forhold til 'medspillende at udfordre' den anden gruppes proces og fremlæggelse, og på hvilken måde man $\mathrm{i}$ egen gruppe har făet eksponeret det enkelte gruppemedlem som særskilt stemme, men samtidig medlem af et fællesskab.

- Kompetence til at disponere stof, relationel proces, analyse, refleksion og konklusion.

- Kompetence til at forholde sig selvrefleksivt til egen proces og produkt.

Stk.2. Eksamensbestemmelser: Prøven er intern og har form af et skriftligt gruppeprojekt på baggrund af udleveret opgaveformulering, og udarbejdes i grupper á 5 personer i løbet af første uge. Projektet skal have et omfang af max 5 sider pr. studerende, ved grupper på to eller tre personer maks. 15 sider. To grupper eksamineres samtidigt. Ved bedømmelsen medvirker intern censor samt to eksaminatorer. Bedømmelsen er individuel. Den mundtlige eksamen varer i alt 3 timer og indeholder egen fremlæggelse, opponering af den anden gruppe, spørgsmål, diskussion og evaluering. Efter lukket votering begrundes bedømmelsen. Opponentgruppens projekt udleveres min. tre dage før mundtlig eksamen. I bedømmelsen indgår såvel det skriftlige projekt samt den mundtlige præstation. Ved bedømmelsen anvendes »bestået " eller "ikke-bestået."

De studerende făr efter eksamen hver især en begrundelse, som forholder sig til kriterierne. Første semester, som i øvrigt har karakter af at være eksemplarisk for hele bachelorstudiet, får således netop tematisk betydning for det at blive studerende på netop dette studium. De har i oversigt været paletten rundt, og vi har rørt ved en række af de vigtige temaer, som gennemarbejdes hen over de følgende $2 \frac{1}{2}$ år.

I tilrettelæggelsen af de senere eksaminationer på studiet har vi i studienævnet tilstræbt, at de studerende møder samme forsøg på sammenhæng mellem undervisning (form og indhold) og eksamensform, samtidig med at vi tilstræber, at studiets eksamensformer også kommer paletten af mulige former rundt.

\section{Litteratur}

Hermansen, Mads, Løw, Ole \& Petersen, Vibeke (2004), Kommunikation og samarbejde i professionelle relationer. Alinea, København. Sternberg, Robert (2003), Måder at toenke på-Tenkestil. Klim, København.

Studieordningen for HApsyk (2005), Copenhagen Business School (Handelshøjskolen).

\section{Noter}

1 De to metoder er eksempler på, hvordan man alternativt kan organisere undervisningen. Se fx for yderligere beskrivelse i Hermansen m.fl. (2004) p. 139, 185 og 129-139.

2 Metoden går i al korthed ud på gennem en netbaseret testning af den enkeltes tænkestil at matche de personer som bedst supplerer hinanden i en arbejdsproces. Da alle stile er principielt lige gode, er der ikke tale om at diagnosticere i gode og dårlige, men netop i god match for samarbejde. 